EUGENIUSZ RYDZ

Pomorska Akademia Pedagogiczna, Słupsk

\title{
Proces ksztaltowania się Słupskiej Specjalnej Strefy Ekonomicznej
}

\section{GENEZA SPECJALNYCH STREF EKONOMICZNYCH}

Recesja gospodarcza z początku lat dziewięćdziesiątych spowodowała, że ważnym zagadnieniem stało się poszukiwanie sposobów wsparcia obszarów zagrożonych recesją gospodarczą i rosnącym bezrobociem. Możliwości takie dawała idea, sprawdzona na Zachodzie, jaką było powoływanie specjalnych stref ekonomicznych, na terenie których inwestujące przedsiębiorstwa mogą liczyć na ulgi i przywileje w zamian za budowę zakładów i tworzenie nowych miejsc pracy. Wzorcem w tym zakresie stała się specjalna strefa ekonomiczna w Shaanon, w Irlandii, która przed wejściem do Unii Europejskiej borykała się z podobnymi jak Polska problemami. Należy nadmienić, iż Shaanon było kiedyś lotniskiem obsługującym ruch atlantycki. Po wprowadzeniu odrzutowców, które nie musiały lądować w celu uzupełnienia paliwa na dalszą drogę, Shaanon przestało spełniać swoją funkcję. Perspektywą była utrata pracy przez kilka tysięcy ludzi oraz zmarnowanie całej infrastruktury tworzonej przez wiele lat. Powstał więc pomysł, aby stworzyć tu sieć sklepów wolnocłowych. W 1959 r. powołano w tym celu strefę ekonomiczną, na terenie której umożliwiano podejmowanie działalności produkcyjnej firmom prywatnym i stwarzano warunki dla przyciagania zagranicznych inwestorów. Dla podniesienia atrakcyjności strefy uproszczono przepisy zakładania nowych firm, zniesiono podatki i zwolniono z opłat celnych wszystkie importowane i eksportowane towary oraz materiały do produkcji na eksport. W efekcie tych działań w 1962 r. liczba nowych miejsc pracy przekroczyła liczbę wcześniej utraconych stanowisk, a trzy lata później ze strefy pochodziło 30\% irlandzkiego eksportu. Efekty były więc stosunkowo szybkie i dobrze widoczne (Polskie Specjalne Strefy..., 2000, s. 30).

Sukces irlandzkiej strefy szybko rozpowszechnił się w świecie. Powstawały kolejne strefy, np. na Tajwanie (1965), w Dominikanie (1969), Malezji (1971), Filipinach (1971), Francji (1980), Wielkiej Brytanii (1984) oraz w wielu krajach Afryki, Ameryki Południowej i Środkowej. W 1994 r. funkcjonowało na świecie około 500 stref ekonomicznych, a w 1997 r. było ich już około 850 (Kryńska 2000).

W Polsce idee tworzenia stref ekonomicznych podjęto na podstawie ustawy uchwalonej z inicjatywy Komitetu Ekonomicznego Rady Ministrów w 1994 r. Według tej ustawy, specjalne strefy ekonomiczne miały obejmować wyodrębnioną niezamieszkałą część tery- 
torium, stworzoną w celu przyspieszenia rozwoju gospodarczego określonych regionów kraju, w szczególności przez:

- rozwój określonych dziedzin działalności gospodarczej,

- rozwój nowych rozwiązań technologicznych,

- wzrost eksportu,

- zagospodarowanie istniejącego majątku przemysłowego,

- tworzenie nowych miejsc pracy,

- zagospodarowanie nie wykorzystanych zasobów naturalnych.

Strefy mogły być usytuowane na gruntach stanowiących własność Skarbu Państwa albo gminy (lub też gmin, w zależności od sytuacji), związku komunalnego lub będących w użyt-

kowaniu wieczystym zarządzającego ${ }^{1}$. Poza tym w przypadkach uzasadnionych ważnymi względami gospodarczymi, część strefy może obejmować grunty stanowiące własność:

- Skarbu Państwa, których użytkownikiem wieczystym jest osoba inna, niż zarządzający za zgodą użytkownika wieczystego,

- osób innych, niż Skarb Państwa, gmina (związek komunalny) i zarządzający za zgodą właściciela.

W kolejnych latach dokonano nowelizacji ustawy o specjalnych strefach ekonomicznych. Nowelizacje były spowodowane koniecznością dostosowania przepisów ustaw o strefach do zasad i ograniczeń w zakresie udzielania pomocy publicznej dla przedsiębiorstw prowadzących działalność gospodarczą na terenie strefy ${ }^{2}$. Sytuacja ta wynikała po części z nacisków Unii Europejskiej na Polskę w czasie prowadzonych negocjacji w sprawie wejścia naszego kraju w struktury europejskie w 2004 r. Kolejna istotna modernizacja przepisów ustawy o specjalnych strefach ekonomicznych nastapiła w 2001 r. i dotyczyła m.in. warunków dopuszczalności i nadzorowania pomocy publicznej dla przedsiębiorstw oraz zasad i warunków przetargów lub rokowań, a także kryteriów oceny zamierzeń co do przedsięwzięć gospodarczych. Zlikwidowane zostało całkowite zwolnienie od podatku. Wysokość ulgi była ustalana m.in. od poziomu bezrobocia, wielkości produktu krajowego (PKB) na jednego mieszkańca regionu, w którym działa strefa ekonomiczna, infrastruktury i poziomu zatrudnienia ${ }^{3}$.

Pierwszą specjalną strefę ekonomiczną w Polsce otwarto jesienią w 1995 r. w Mielcu. Już wtedy docierały poważne oferty z USA, Niemiec, Francji, Wielkiej Brytanii, reprezentujące głównie branżę motoryzacyjną, budowlaną, agrobiznes. Na wieść o ulgach podatkowych - nazwanych w żargonie ,plastrem miodu”, który przyciaga inwestorów do małej specjalnej strefy ekonomicznej, zaczęły napływać z całego kraju projekty przedsięwzięć ${ }^{4}$. Zdecydowana większość regionów objętych strukturalnym bezrobociem domagała się takiego obszaru, widząc w nim istotny instrument ożywienia ekonomicznego. Wojewodowie zabiegając o utworzenie specjalnych stref ekonomicznych musieli najpierw przygotować szczegółowy projekt i biznesplan, który wstępnie oceniał minister przemysłu, a ostateczną decyzje podejmowała Rada Ministrów. Czynione przez władze regionalne starania dopro-

\footnotetext{
${ }^{1}$ Dz. U. z 1994 r., Nr 123, Art. 5 ustawy o specjalnych strefach ekonomicznych.

${ }^{2}$ Dz. U. z 2000 r., Nr 117, poz. 1223 i Dz. U. z 2000 r., nr 60, poz. 704 o warunkach dopuszczalności i nadzorowaniu pomocy publicznej dla przedsiębiorstw.

${ }^{3}$ Dz. U. z 2000 r., Nr 117, poz. 1228. Ustawa z dnia 16.11. o zmianie ustawy o specjalnych strefach ekonomicznych.

${ }^{4}$ Plaster na rany, „Polityka” z 9.03.1996 r., nr 10, s. 64-65.
} 
wadziły do utworzenia do roku 1998 aż 17 specjalnych stref ekonomicznych, w tym dwóch technoparków: Krakowskiego Parku Technologicznego i Technoparku Modlin (ryc. 1). W 2001 r. zostały zlikwidowane dwie strefy - Częstochowska Specjalna Strefa Ekonomiczna oraz Technopark Modlin 5 .

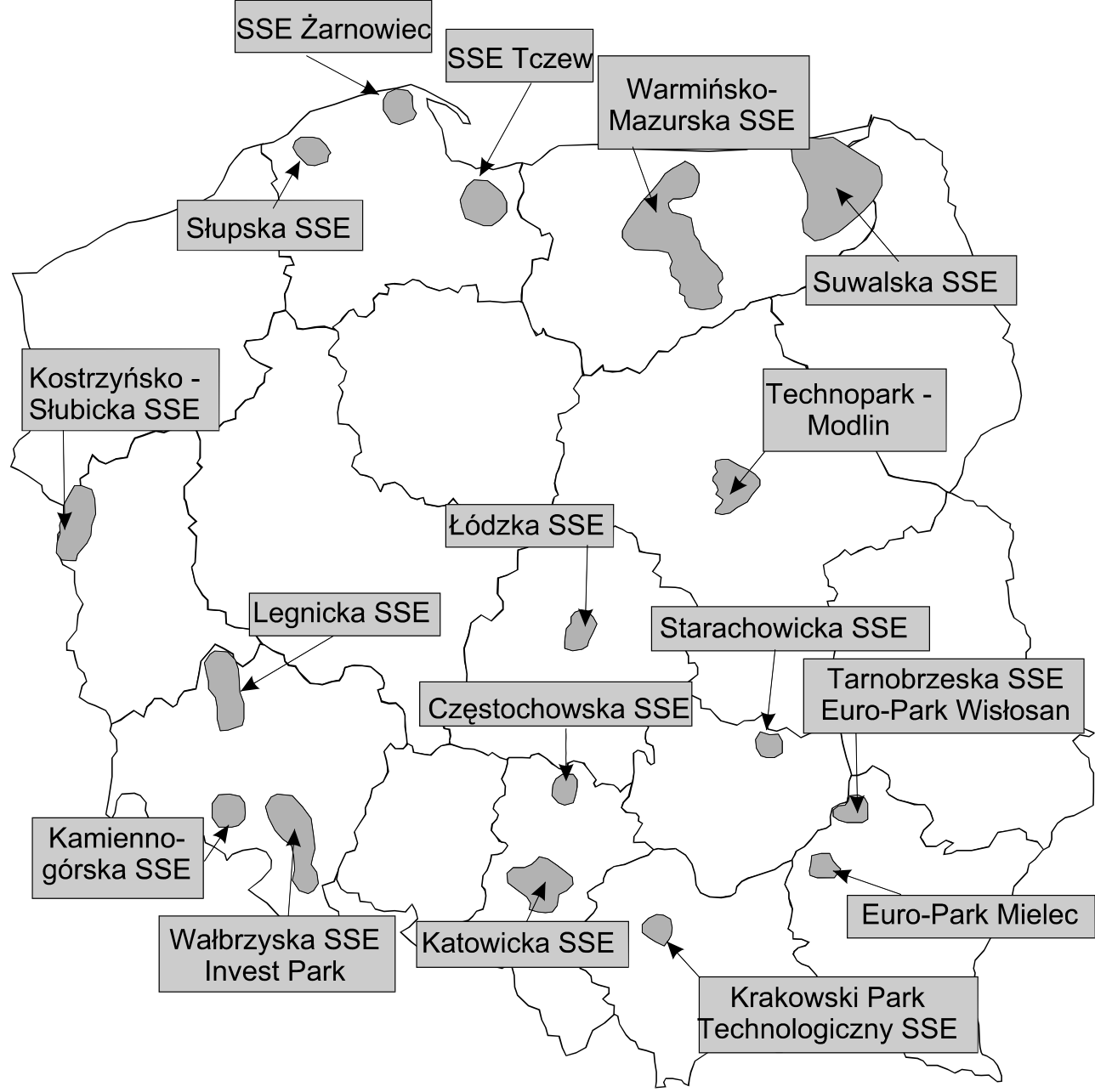

Ryc. 1. Rozmieszczenie specjalnych stref ekonomicznych w Polsce w 1998 r.

Przyglądając się regionom, w których powstały specjalne strefy ekonomiczne oraz analizując literaturę przedmiotu można wyodrębnić kilka charakterystycznych grup stref ze względu na cel, dla realizacji którego zostały powołane (Kryńska 2000). Najczęściej strefy stanowią narzędzie restrukturyzacji starych okręgów przemysłowych, np.:

${ }^{5}$ Rozporządzenie Rady Ministrów z dnia 13 marca 2001 r. w sprawie zniesienia Mazowieckiej Specjalnej Strefy Ekonomicznej (Dz. U. 30/01, poz. 341) i Specjalnej Strefy Ekonomicznej w Częstochowie (Dz. U. 30/01, poz. 340). 
- restrukturyzacja przemysłu wydobywczego wegla kamiennego i związanego z nim przemysłu ciężkiego (Katowicka i Wałbrzyska SSE);

- restrukturyzacja przemysłu wydobywczego miedzi (Legnicka SSE);

- dywersyfikacja struktury gospodarczej regionu - monokultura przemysłu związanego z wydobyciem i przetwórstwem siarki (Tarnobrzeska SSE);

- restrukturyzacja Wytwórni Sprzętu Komunikacyjnego PZL Mielec (Mielecka SSE);

- restrukturyzacja przemysłu lekkiego (Łódzka SSE);

- restrukturyzacja Staropolskiego Okręgu Przemysłowego (Starachowicka SSE).

Innym celem utworzenia SSE było:

- aktywizowanie rozwoju gospodarczego regionów o niskim poziomie rozwoju gospodarczego (Słupska SSE, Suwalska SSE, Warmińsko-Mazurska SSE);

- ograniczenie wysokiego bezrobocia strukturalnego (Kamiennogórska SSE, Częstochowska SSE, Tczewska SSE);

- wykorzystanie przygranicznego położenia (Kostrzyńsko-Słubicka SSE, Suwalska SSE);

- zagospodarowanie zaplecza naukowo-badawczego (Krakowski Park Technologiczny, Technopark Modlin).

Aktualnie istnieje w kraju 14 stref ekonomicznych. Z powołanych wcześniej dwie strefy uległy likwidacji: Częstochowska Specjalna Strefa Ekonomiczna i Technopark Modlin, zwany też Mazowiecką Specjalną Strefą Ekonomiczną. Przeważa opinia, że strefy te powołano bez należytego przygotowania, pewne działania zostały podjęte zbyt pochopnie i z niepotrzebnym pośpiechem, na fali kampanii wyborczej do parlamentu w $1997 \mathrm{r}$. Pewnym utrudnieniem były nie do końca uporządkowane stosunki własnościowe gruntów. Godny podkreślenia jest również fakt, że w $2001 \mathrm{r}$. z połączenia SSE Tczew i SSE Żarnowiec powstała Pomorska Specjalna Strefa Ekonomiczna. Połączenie strefy tczewskiej i żarnowie-

ckiej w Pomorską SSE miało zasadniczo na celu uproszczenie struktury organizacyjnej i ograniczenie kosztów funkcjonowania spółki zarządzającej, podniesienie rangi marketingowej strefy oraz wpisanie zadań dotyczących funkcjonowania strefy do programu rozwoju regionalnego województwa pomorskiego.

$\mathrm{Na}$ tle ogólnie zarysowanych problemów dotyczących koncepcji powstawania stref ekonomicznych w Polsce celem prezentowanego artykułu jest charakterystyka Słupskiej Specjalnej Strefy Ekonomicznej ze szczególnym uwzględnieniem zjawisk dotyczących procesu jej kształtowania się, a także określenie miejsca, jakie zajmuje wśród funkcjonujących w kraju tego typu jednostek.

\section{Powstanie SŁUPSKIEJ SPeCJALNEJ STREFy EKONOMICZNEJ}

Pomysł utworzenia Słupskiej Specjalnej Strefy Ekonomicznej powstał w Słupsku w 1995 r., wkrótce po ukazaniu się ustawy o strefach ekonomicznych. Inicjatorem tej idei była Pomorska Agencja Rozwoju Regionalnego S.A. Koncepcja powołania SSSE przedstawiona została tutejszym parlamentarzystom, władzom miasta i wojewodzie. Początkowo brak było przekonania co do słuszności powstania strefy. Pewne trudności wynikały 
z braku zgodności co do obszaru, na którym miałaby funkcjonować strefa. Innym mankamentem był brak zainteresowania ze strony podmiotów gospodarczych, przyszłych inwestorów. Kolejne działanie dotyczące powołania Słupskiej Specjalnej Strefy Ekonomicznej podjęto w stycz-

niu 1996 r. z inicjatywy wojewody słupskiego. Województwo słupskie spełniało bowiem wszystkie wymagania zawarte w ustawie o SSE, a w dokumentach Ministerstwa Handlu wymieniane było jako przykład, gdzie strefa może powstać. Zdaniem inicjatorów powołanie do życia strefy ekonomicznej miało przyczynić się do przezwyciężenia ujemnych skutków restrukturyzacji oraz do ożywienia miejscowej gospodarki i zmniejszenia skutków bezrobocia.

We wniosku wojewody słupskiego o ustanowienie specjalnej strefy ekonomicznej jako główne cele jej utworzenia wskazano:

- zwiększenie dochodów ludności (wyrównywanie ich do średniej krajowej) na skutek zwiększenia liczby miejsc pracy w strefie oraz poza nią;

- zwiększenie konkurencyjności wytwarzanych wyrobów i świadczonych usług;

- zagospodarowanie istniejącego majątku przemysłowego i infrastruktury gospodarczej;

- zagospodarowanie niewykorzystanych zasobów naturalnych z zachowaniem zasad równowagi ekologicznej;

- poprawę warunków i podniesienie atrakcyjności życia w regionie słupskim;

- stworzenie perspektyw rozwoju osobistego młodzieży, co przyczynić się miało do zmniejszenia stopnia ujemnej migracji.

Ustanowiona decyzją rządu 9 września 1997 r. Słupska Specjalna Strefa Ekonomiczna obejmuje obszar o powierzchni 168 ha, składający się z dwu kompleksów (ryc. 2). Kompleks podstawowy Słupsk-Włynkówko położony jest na terenie przemysłowym, w północno-zachodniej części Słupska, $2 \mathrm{~km}$ od centrum miasta. Obejmuje on powierzchnię 109 ha. W północno-zachodniej części tereny miejskie strefy łączą się z częścią strefy, leżącą w granicach administracyjnych gminy wiejskiej Słupsk. Na terenie tym położona jest dawna fabryka domów z wieloma obiektami (np. stalowa hala produkcyjna, kotłownia, hala montażu itp.). Jest to generalnie obszar o dość dobrym zainwestowaniu struktury technicznej (doprowadzona energia elektryczna, woda, oczyszczalnia chemiczna oraz urządzenia oczyszczające, w tym łapacze olei i zanieczyszczeń pochodzenia mineralnego). Bezpośrednio w pobliżu strefy, po drugiej stronie rzeki Słupi, zlokalizowana jest miejska oczyszczalnia ścieków.

Bardzo ważna dla inwestorów jest sieć dróg. Korzystny układ komunikacyjny kompleksu Słupsk-Włynkówko stwarza biegnąca przez teren strefy droga wojewódzka łącząca Ustkę ze Słupskiem oraz zelektryfikowana linia kolejowa, przystosowana do ruchu pasażerskiego i towarowego. W bieżącym roku Pomorska Agencja Rozwoju Regionalnego S.A., miasto Słupsk oraz gmina Słupsk wspólnie rozpoczęły budowę drogi, która połączy tereny strefy z ulicami Grunwaldzką oraz Sobieskiego, aż do drogi międzynarodowej E-28 Berlin - Szczecin - Gdańsk - Kaliningrad.

W odległości $15 \mathrm{~km}$ od granicy strefy znajduje się port handlowo-rybacki w Ustce, na terenie którego działa posterunek celny podległy oddziałowi w Słupsku. Jednostki te oferują pełen zakres odpraw celnych w zakresie eksportu i importu dla towarów wytworzonych w Specjalnej Strefie Ekonomicznej. W porcie usteckim znajduje się m.in. elewator zbożowy o pojemności 5 tys. ton oraz pełna infrastruktura pozwalająca na obsługę jednostek średniego tonażu. Port w Ustce jest w stanie przyjąć jednostki pływające o następujących 
parametrach: długość 58 m, szerokość $11 \mathrm{~m}$ i głębokość zanurzenia 4,5 m. Godny podkreślenia jest również fakt, że na terenach przyległych do nabrzeży rozpoczęto budowę pierwszej w Polsce aukcji rybnej, która stanie się doskonałą bazą surowcową dla przedsiębiorstw z branży przetwórstwa rybnego zlokalizowanych w Strefie (już obecnie funkcjonują tu Zakłady Przetwórstwa Rybnego „ŁOSOS” Sp. z o.o., zatrudniające ponad 200 osób).

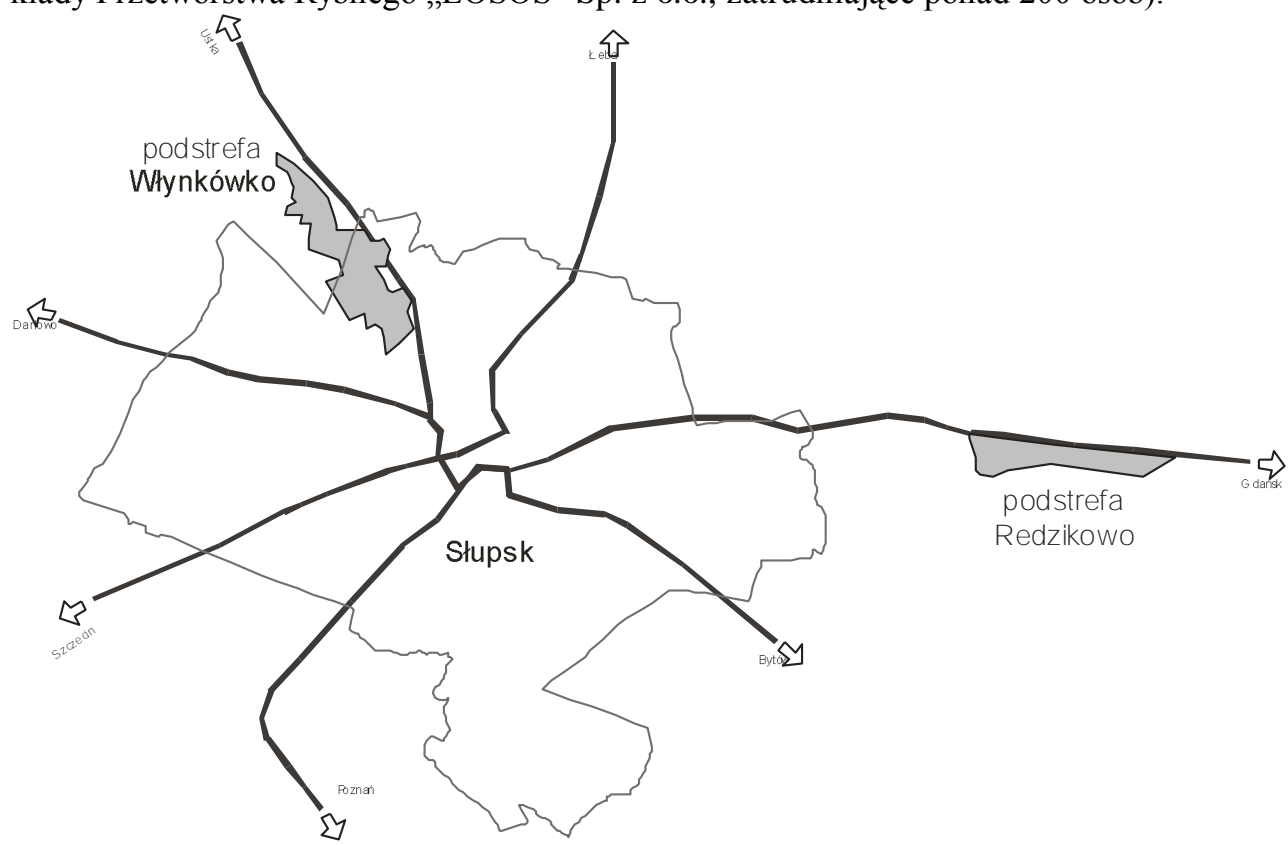

Ryc. 2. Położenie Słupskiej Specjalnej Strefy Ekonomicznej

Nowy obszar SSSE obejmuje kompleks Redzikowo o powierzchni 59 ha, który położony jest wzdłuż drogi międzynarodowej E-28 (ryc. 2). Na terenie kompleksu planowane jest ujście obwodnicy miasta Słupska wraz z węzłem komunikacyjnym. Aktualnie trwają tu prace mające na celu zmianę planu ogólnego zagospodarowania przestrzennego dla obszaru Wieszyna i Redzikowa. W przyszłym roku Pomorska Agencja Rozwoju Regionalnego planuje rozpoczęcie prac, mających na celu zapewnienie niezbędnej infrastruktury technicznej dla pierwszych inwestorów. Warto nadmienić, że do transportu wytworzonych na tym terenie wyrobów może być z powodzeniem wykorzystane byłe lotnisko wojskowe w Redziko-

wie, położone w odległości około $1 \mathrm{~km}$ od Strefy. Posiada ono dwupasmową drogę dojazdową, pas startowy o długości $2400 \mathrm{~m}$ i szerokości $60 \mathrm{~m}$, plac postojowy o wymiarach $60 \times 105 \mathrm{~m}$ oraz terminal z zapleczem do obsługi ruchu cargo.

\section{KSZTAŁTOWANIE SIE SŁUPSKIEJ SPECJALNEJ STREFy EKONOMICZNEJ}


Powołując w Polsce specjalne strefy ekonomiczne rząd musiał przyjąć taką strategię działania, która byłaby w stanie przyciagnąć potencjalnych inwestorów. Państwo stworzyło zatem system ulg, które miały być istotnym czynnikiem w pozyskiwaniu przyszłych przedsiębiorców. Specjalne warunki prowadzenia inwestycji w Słupskiej Specjalnej Strefie Ekonomicznej można zasadniczo podzielić na trzy rodzaje:

- zwolnienia od podatku dochodowego dochodu uzyskanego z działalności gospodarczej od kwoty wydatków inwestycyjnych;

- zwolnienia od podatku dochodowego dochodu uzyskanego z działalności gospodarczej w zależności od osiągnięcia przez podatnika określonego poziomu zatrudnienia;

- zwolnienia od podatku od nieruchomości.

Na podstawie przepisów ustawy o specjalnych strefach ekonomicznych obowiązujących do końca 2000 r., przedsiębiorca, który uzyskał zezwolenie na prowadzenie działalności w strefie przed 1 stycznia 2001 r. może korzystać - przy spełnieniu określonych warunków - z całkowitego zwolnienia od podatku dochodowego w okresie pierwszych 10 lat prowadzenia działalności i do $50 \%$ zwolnienia od podatku w pozostałym okresie istnienia strefy, czyli do 2017 roku. Inwestowanie w strefie wiąże się także z niewymiernymi korzyściami, jak pomoc prawna i organizacyjna oferowana przez spółki zarządzające strefami, np. w zakresie uzyskania zezwolenia na nabycie nieruchomości lub obsługa inwestorów SSSE.

W okresie negocjacji na temat warunków przystąpienia naszego kraju do Unii Europejskiej ujawniły się pewne rozbieżności w obszarze konkurencji. Komisja Europejska wykazała, że system pomocy publicznej udzielanej w ramach Specjalnych Stref Ekonomicznych był sprzeczny z podpisanym przez Polskę w roku 1992 Układem Europejskim. Do najważniejszych różnic zaliczono m.in.: brak limitów poziomu pomocy udzielanej poszczególnym przedsiębiorcom, brak ograniczenia pomocy dla sektorów wrażliwych (np. motoryzacja, produkcja włókien syntetycznych) oraz brak dostatecznej przejrzystości i monitoro-

wania udzielanej pomocy w postaci ulg podatkowych. W związku z tymi zastrzeżeniami z dniem 1 stycznia 2001 r. weszła w życie ustawa o warunkach dopuszczalności i nadzorowaniu pomocy publicznej dla przedsiębiorstw, która normuje zasady i warunki udzielania pomocy w Polsce, zgodnie z prawem obowiązującym w Unii Europejskiej ${ }^{6}$. Od tego momentu obowiązują nowe zasady udzielania pomocy regionalnej w specjalnych strefach ekonomicznych, które w pełni respektują uwarunkowania ustawy o ,pomocy publicznej dla przedsiębiorstw".

Warunkiem korzystania z pomocy regionalnej jest uzyskanie zezwolenia, które w imieniu ministra gospodarki wydaje Pomorska Agencja Rozwoju Regionalnego. Obowiązujące przepisy określają minimalną wysokość nakładów inwestycyjnych na poziomie 100 tys. euro, specyfikują cel społeczno-ekonomiczny stref - dający gwarancje stworzenia miejsc pracy przez minimum pięć lat. Według nowych zasad podstawową korzyścią, jaką uzyskują inwestorzy strefowi, to zwrot nakładów inwestycyjnych w formie zwolnienia od podatku dochodowego w wysokości do 50\% wydatków inwestycyjnych dla każdego przedsiębiorcy zatrudniającego powyżej 250 pracowników oraz do $65 \%$ wydatków inwestycyjnych dla przedsiębiorcy „małego” lub „średniego”, zatrudniającego mniej niż 250 pracow-

${ }^{6}$ Dz. U. Nr 60, poz. 704. 
ników. Poza tym ważnym czynnikiem zachęcającym do inwestowania na terenie strefy ekonomicznej są ulgi lokalne. Corocznie uchwałą Rady Miasta Słupska przedsiębiorcy inwestujący w SSSE są zwolnieni z podatku od nieruchomości. Według najnowszych projektów zmian w ustawie o strefach planowane jest ustawowe zwolnienie z podatków lokalnych.

Funkcjonowanie specjalnych stref ekonomicznych w Polsce miało być czynnikiem przyspieszającym rozwój gospodarczy regionów poprzez zwiększenie ich atrakcyjności inwestycyjnej. Powołana w 1997 r. Słupska Specjalna Strefa Ekonomiczna miała stać się także skutecznym narzędziem w ograniczeniu wciąż wysokiego bezrobocia w subregionie słupskim. Jej działalność oparta została na obowiązujących dla wszystkich działających w kraju, w tym także dla SSSE aktach prawnych ${ }^{7}$.

Utrzymujące się tendencje gospodarcze i społeczne w ostatnich pięciu latach w skali całego kraju, jak i w układzie regionalnym z różnym skutkiem wpływały na podejmowane decyzje o rozpoczęciu działalności na terenie Słupskiej Specjalnej Strefy Ekonomicznej. Niemniej jednak na uwagę zasługuje fakt, że w okresie pięcioletniego istnienia strefy (lata 1997-2002) wydano 21 zezwoleń, w tym 3 zaświadczenia na prowadzenie działalności na jej terenie (tab. 1). Spośród tych inwestorów działalność produkcyjną rozpoczęło 12 zakładów oraz 3 firmy usługowe, które na koniec września 2002 r. zatrudniały łącznie 753 oso-

\footnotetext{
${ }^{7}$ Słupska Specjalna Strefa Ekonomiczna funkcjonuje na podstawie następujących aktów prawnych: - Rozporządzenie Rady Ministrów z dnia 9 września 1997 r. w sprawie ustanowienia Słupskiej Specjalnej Strefy Ekonomicznej, Dz.U. z dnia 31 października 1997 r., Nr 135, poz. 905,

- Ustawa o specjalnych strefach ekonomicznych z dnia 20 października 1994 r. Dz.U. Nr 123, poz. 600 z późniejszymi zmianami (tekst jednolity)

- Ustawa z dnia 30 czerwca 2000 r. o warunkach dopuszczalności i nadzorowaniu pomocy publicznej dla przedsiębiorców, Dz.U. Nr 60, poz. 704,

- Ustawa z dnia 16 listopada 2000 r. o zmianie ustawy o specjalnych strefach ekonomicznych oraz zmianie niektórych ustaw, Dz.U. z dnia 23 grudnia 2000 r., Nr 117, poz. 1228,

- Rozporządzenie Rady Ministrów z dnia 20 lutego 2001 r. w sprawie pomocy regionalnej dla przedsiębiorców, Dz.U. z dnia 4 kwietnia 2001 r., Nr 28, poz. 306,

- Rozporządzenie Rady Ministrów z dnia 13 marca 2001 r. zmieniające rozporządzenie w sprawie ustanowienia Słupskiej Specjalnej Strefy Ekonomicznej, Dz.U. z dnia 9 kwietnia 2001 r., Nr 30, poz. 334,

- Rozporządzenie Ministra Gospodarki z dnia 13 czerwca 2001 r. w sprawie powierzenia Pomorskiej Agencji Rozwoju Regionalnego S.A. udzielania zezwoleń na prowadzenie działalności gospodarczej oraz wykonywania bieżącej kontroli działalności przedsiębiorców na terenie Słupskiej Specjalnej Strefy Ekonomicznej oraz ustalenie zakresu tej kontroli, Dz.U. z dnia 29 marca 2001 r., Nr 76, poz. 702,

- Rozporządzenie Rady Ministrów z dnia 21 sierpnia 2001 r. zmieniające rozporządzenie w sprawie ustanowienia Słupskiej Specjalnej Strefy Ekonomicznej, Dz.U. z dnia 1 października 2001 r., Nr 107, poz. 1175,

- Rozporządzenie Ministra Gospodarki z dnia 27 stycznia 1998 r. w sprawie sposobu przeprowadzania, zasad i warunków przetargów lub rokowań oraz kryteriów oceny zamierzeń co do przedsięwzięć gospodarczych, które mają być podjęte przez przedsiębiorców, na terenie Słupskiej Specjalnej Strefy Ekonomicznej. Dz.U. nr 22, poz. 103 ,

- Rozporządzenie Ministra Gospodarki z dnia 27 stycznia 1998 r. w sprawie powierzenia Pomorskiej Agencji Rozwoju Regionalnego S.A. udzielania zezwoleń na prowadzenie działalności gospodarczej oraz wykonywania bieżącej kontroli działalności przedsiębiorców na terenie Słupskiej Specjalnej Strefy Ekonomicznej oraz ustalenia zakresu tej kontroli. Dz.U. nr 22, poz. 104,

- Rozporządzenie Ministra Gospodarki z dnia 16 marca 1998 r. w sprawie ustalenia planu rozwoju Słupskiej Specjalnej Strefy Ekonomicznej. Dz.U. nr 43, poz. 259

- Rozporządzenie Ministra Gospodarki z dnia 29 marca 2001 r. w sprawie sposobu przeprowadzenia, zasad i warunków przetargów lub rokowań oraz kryteriów oceny zamierzeń co do przedsięwzięć gospodarczych, które mają być podjęte przez przedsiębiorców na terenie Słupskiej Specjalnej Strefy Ekonomicznej. Dz.U. nr 37, poz. 443
} 
by. Z przeprowadzonych badań wynika, że od 1998 r., kiedy wydano pierwsze zezwolenia na prowadzenie działalności gospodarczej na terenie strefy (otrzymało je pięć firm), w kolej-

nych latach obserwuje się dość wyraźną tendencję wzrostu udzielonych zezwoleń, a co jest szczególnie ważne, zwiększenie nakładów inwestycyjnych i liczby zatrudnionych (ryc. 3). Już obecnie można przyjąć, że zakładany sposób aktywizacji znajdującego się w głębokiej depresji gospodarczej subregionu słupskiego poprzez inwestycje w strefie ekonomicznej przynosi pewne efekty. Według wiążących deklaracji i wydanych dotychczas zezwoleń, na terenie słupskiej Strefy ma powstać łącznie około 1500 nowych miejsc pracy do końca 2004 r. Do firm o największych inwestycjach należy Zakład Wyrobów Metalowych „STAKO” s.c. (produkcja zbiorników ciśnieniowych), „ZASTA-POLSKA” Sp. z o.o. (produkcja cystern drogowych i kolejowych), „COM” Sp. z o.o. (branża poligraficzna i papiernicza), Przetwórstwo Rybne „ŁOSOS” Sp. z o.o. (produkcja konserw rybnych).

Tabela 1. Firmy, które uzyskały zezwolenie na prowadzenie działalności gospodarczej na terenie Słupskiej Specjalnej Strefy Ekonomicznej

\begin{tabular}{|c|c|c|c|}
\hline Lp. & Firma & $\begin{array}{c}\text { Data wyda- } \\
\text { nia zezwole- } \\
\text { nia }\end{array}$ & Rodzaj działalności \\
\hline 1. & „DŹWIGBUD” s. c. & $15.10 .1998 *$ & $\begin{array}{l}\text { Usługi przewozowe towarów wyspecjali- } \\
\text { zowanymi pojazdami }\end{array}$ \\
\hline 2. & PPPB „PROBET” s. c. & 15.10 .1998 & Produkcja wyrobów betonowych \\
\hline 3. & PPH „DOMBET” s. c. & 15.10 .1998 & Produkcja wyrobów betonowych \\
\hline 4. & Firma „BAJCAR” Sp. z o.o. & 31.12 .1998 & $\begin{array}{l}\text { Produkcja stolarki budowlanej, wyroby } \\
\text { z tworzyw sztucznych }\end{array}$ \\
\hline 5. & PPU „SOBCAR” Sp. z o.o. & 14.05 .1999 & $\begin{array}{l}\text { Produkcja części do pojazdów mechanicz- } \\
\text { nych i ich silników }\end{array}$ \\
\hline 6. & „MEBLOSTAL-WIK” & 21.06 .1999 & $\begin{array}{l}\text { Produkcja mebli z wikliny i stolarki bu- } \\
\text { dowlanej }\end{array}$ \\
\hline 7. & „COM”Sp. z o. o. & 30.12 .1999 & Produkcja poligraficzna \\
\hline 8. & $\begin{array}{l}\text { Usługi Sprzętowo-Transportowe } \\
\text { Henryk Lipiński }\end{array}$ & $22.12 .1999 *$ & $\begin{array}{l}\text { Usługi przewozowe towarów wyspecjali- } \\
\text { zowanymi pojazdami }\end{array}$ \\
\hline 9. & $\begin{array}{l}\text { Usługi Transportowe } \\
\text { Wiesław Czechowicz }\end{array}$ & $15.05 .2000^{*}$ & $\begin{array}{l}\text { Usługi przewozowe towarów wyspecjali- } \\
\text { zowanymi pojazdami }\end{array}$ \\
\hline 10. & „SLUZAN”Sp. z o.o. & 15.05 .2000 & $\begin{array}{l}\text { Produkcja zabawek i wyrobów metalo- } \\
\text { wych do użytku domowego }\end{array}$ \\
\hline 11. & „M\&S Okna i Drzwi” Sp. z o.o. & 12.09 .1999 & Produkcja stolarki budowlanej \\
\hline 12. & PW "EGIDA"Sp. z o.o. & 31.12 .1998 & $\begin{array}{l}\text { Produkcja materiałów budowlanych, kon- } \\
\text { strukcje metalowe }\end{array}$ \\
\hline 13. & „KAMIR” Sp. z o.o. & 12.09 .2000 & Produkcja elementów metalowych \\
\hline 14. & „ZASTA-POLSKA” Sp. z o. o. & 31.12 .1998 & Produkcja zbiorników i cystern bimodalnych \\
\hline 15. & $\begin{array}{l}\text { Przedsiębiorstwo Rybne } \\
\text { ŁOSOŚ” Sp. z o.o. }\end{array}$ & 20.10 .2000 & Produkcja konserw rybnych \\
\hline 16. & $\begin{array}{l}\text { Zakład Wyrobów Metalowych } \\
\text { „STAKO” Sp. z o.o. }\end{array}$ & 30.12 .2000 & Produkcja zbiorników ciśnieniowych \\
\hline 17. & „JB Auto Trade” Sp. z o.o. & 30.12 .2000 & Meble biurowe \\
\hline
\end{tabular}




\begin{tabular}{|l|l|l|l|}
\hline 18. & $\begin{array}{l}\text { Bałtyckie Towarzystwo } \\
\text { Handlowe S.A. }\end{array}$ & 30.12 .2000 & Przetwórstwo rybne \\
\hline 19. & „ELTEK” Sp. z o.o. & 30.12 .2000 & Produkcja alternatorów i rozruszników \\
\hline 20. & „MILAREX” Sp. z o.o. & 30.12 .2000 & Przetwórstwo rybne \\
\hline 21. & „RAYAN” Sp. z o.o. & 13.12 .2001 & $\begin{array}{l}\text { Produkcja wyrobów metalowych, usługi } \\
\text { transportowe }\end{array}$ \\
\hline
\end{tabular}

* Firmy nie uzyskały zezwolenia, a jedynie zaświadczenia o prowadzeniu działalności gospodarczej w SSSE, gdyż rodzaj działalności usługowej, którą prowadzą nie wymaga uzyskania zezwolenia, a jedynie nabycia prawa do zakupu nieruchomości

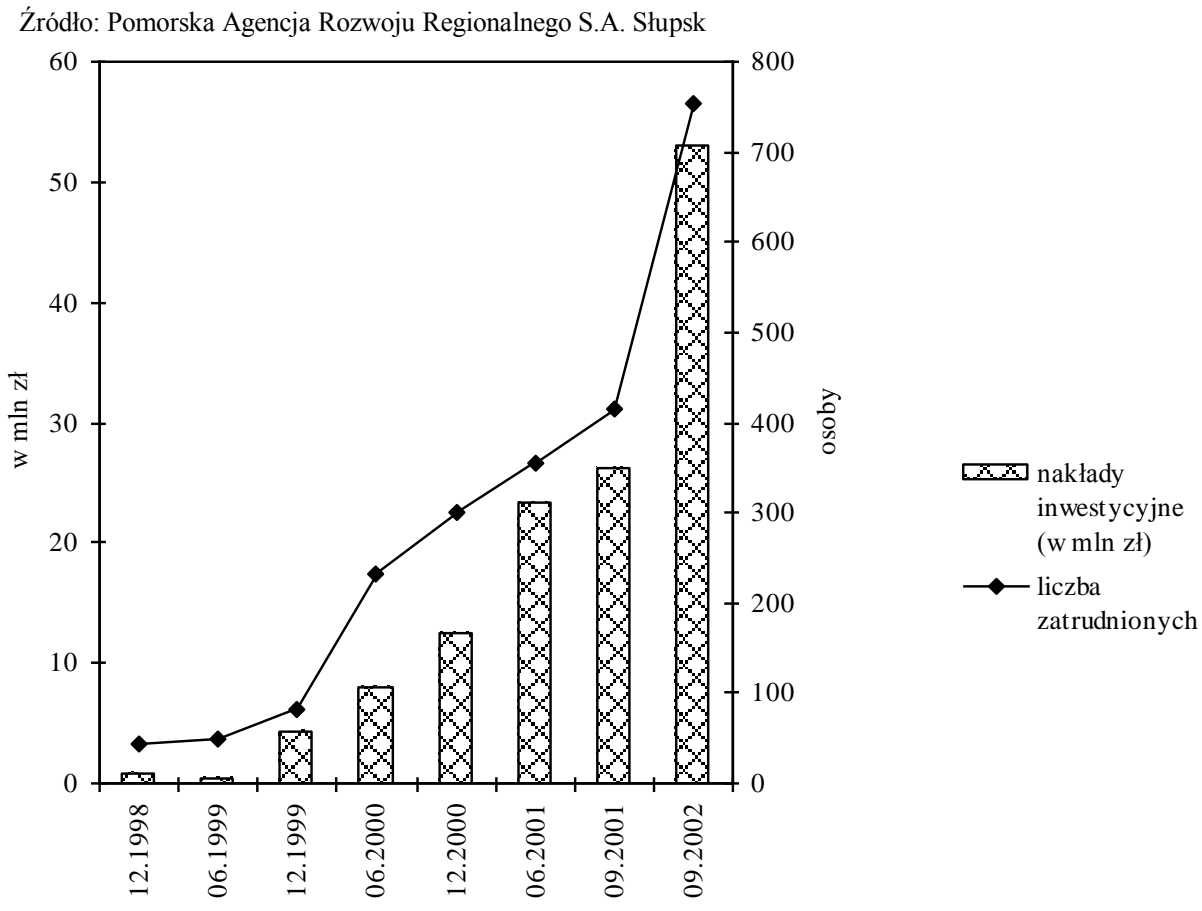

Ryc. 3. Rozwój Słupskiej Specjalnej Strefy Ekonomicznej w latach 1998-2002

Większość działających aktualnie w SSSE firm pochodzi z subregionu słupskiego, np. Przetwórstwo Rybne „ŁOSOŚ” Sp. z o.o. z Ustki, „MILAREX” Sp. z o.o. (Duninowo koło Ustki), Przedsiębiorstwo Produkcyjno-Usługowe „SOBCAR” Sp. z o.o.; jedynie firma „COM”Sp. z o.o. pochodzi z Poznania. Prawie wszystkie firmy zarejestrowane w Strefie bazują na kapitale polskim, jedynie firmy „SLUZAN” Sp. z o.o. i „RAYAN” Sp. z o.o. posiadają mieszany kapitał polski i holenderski. Pewnym utrudnieniem w prawidłowym funkcjonowaniu strefy ekonomicznej jest brak inwestora strategicznego, takiego, który byłby siłą napędową dla pozostałych firm i swego rodzaju magnesem, czynnikiem przyciągającym do strefy inne firmy (inwestorów). Prowadzone w przeszłości rozmowy z koncernem samochodowym KIA MOTORS nie dały pożądanych efektów. Pewien wpływ na taką sytuację miały decyzje rządu, który skłaniał się bardziej do tego, aby KIA prowa- 
dziła inwestycje na Śląsku. W efekcie prowadzonych negocjacji KIA MOTORS tak się zniechęciła do inwestycji w Polsce, że postanowiła rozpocząć produkcję w innych krajach Europy.

Interesującym problemem badawczym w zakresie prowadzonej działalności gospodarczej w strefach ekonomicznych jest określenie kosztów przypadających na jedno utworzone miejsce pracy. Ponieważ niektóre firmy dopiero co rozpoczęły produkcję, precyzyjne ich określenie nastręcza pewne trudności. Istnieje jednak ewentualna możliwość ich oszacowania na podstawie zadeklarowanych kwot oraz określonych miejsc pracy (ryc. 4). Z uzyskanych materiałów wynika, że najwyższe nakłady, ponad 100 tys. zł. na utworzone jedno miejsce pracy, zadeklarowały dwie firmy: „COM” Sp. z o.o. (branża poligraficzna) oraz „SLUZAN” Sp. z o.o. (produkcja zabawek i wyrobów metalowych do użytku domowego). Pewien wpływ na taki stan rzeczy ma również fakt, że obie firmy zatrudniają niewiele

ponad 30 osób, przy jednocześnie dużych nakładach inwestycyjnych.

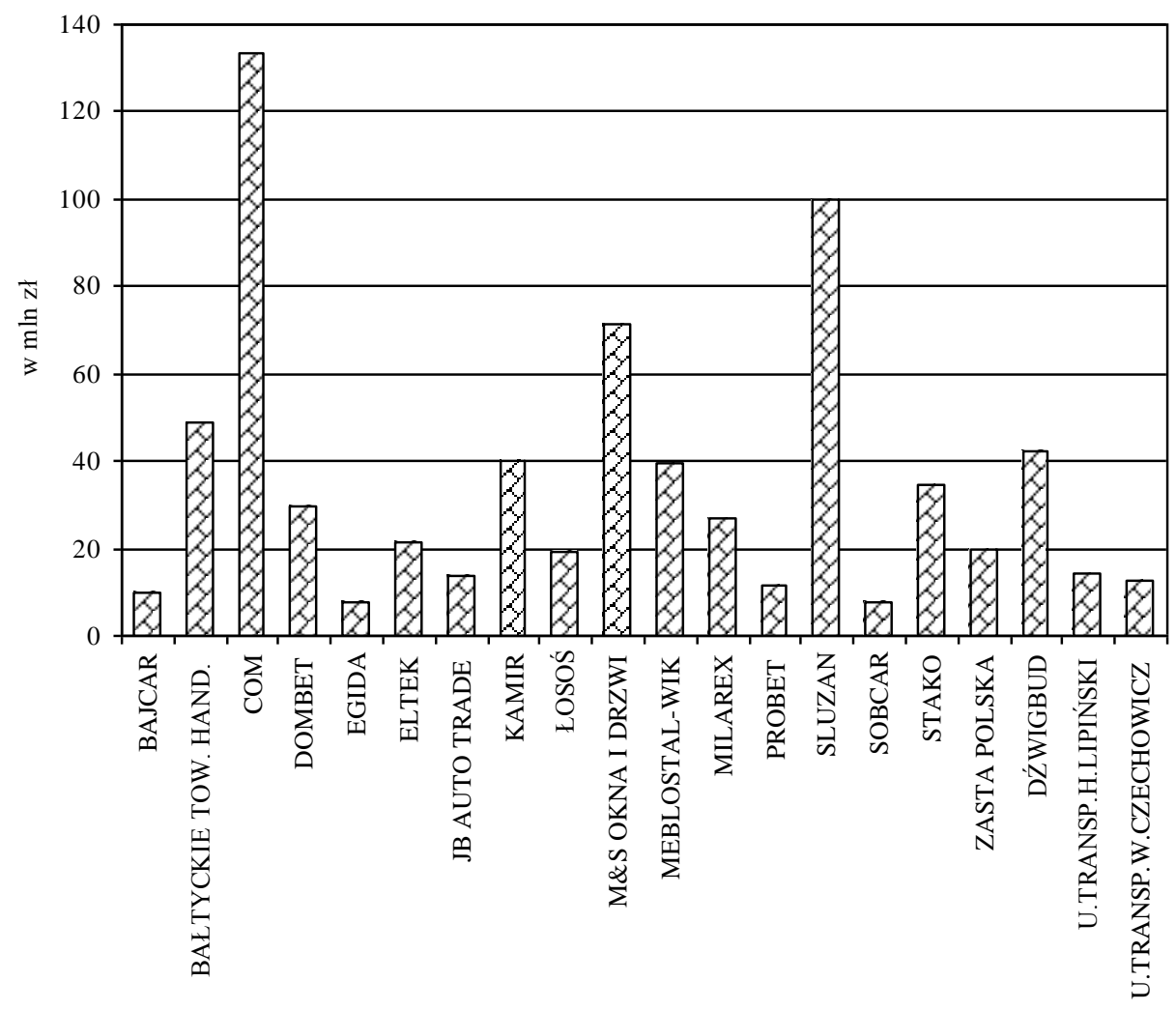

Ryc. 4. Wysokość zadeklarowanej kwoty przypadającej na jedno planowane miejsce pracy

Ważnym zagadnieniem jest zakup działek pod inwestycje na terenie SSSE. Do dyspozycji inwestorów, którzy wyrazili chęć podjęcia działalności gospodarczej, przygotowano grunty o powierzchni 168 ha. Do końca września 2002 r. przedsiębiorcy wykupili 48,35 
ha, co stanowi około 29\% powierzchni Słupskiej SSE. Na jedną firmę przypada średnio 2,3 ha. Zdecydowanie najwięcej jest przedsiębiorstw, które zakupiły działki o powierzchni poniżej 1 ha (ryc. 5).

Ciekawie przedstawia się też położenie wykupionych działek na terenie strefy. Rozpatrując ich lokalizację, przedsiębiorstwa można generalnie podzielić na dwie wyraźne grupy:

- pierwsza grupa skupia się na terenie byłej fabryki domów i w jej bezpośrednim sąsiedztwie. Tereny te były atrakcyjne pod względem infrastruktury technicznej i to spowodowało, że zostały one wykupione najwcześniej („DOMBET” Sp. j., „PROBET” s.c., „ZASTA-POLSKA” Sp. z o.o., „EGIDA”). Kolejne dwie firmy („ŁOSOŚ” Sp. z o.o. i „JB Auto Trade” Sp. z o.o.) ulokowały się w pobliżu tego kompleksu;

- druga grupa inwestorów skupia się bezpośrednio przy drodze nr 210 Słupsk - Ustka (jedna grupa w centralnej części, druga w jej południowej części). Pewnym utrudnieniem wewnątrz strefy jest brak sieci dróg o twardej nawierzchni, co stanowi pewną bariere i podnosi koszty inwestycji. Zaznaczyć należy, że firmy zlokalizowane przy drodze wylotowej na Ustkę, która zwłaszcza latem jest uczęszczana, same mogą się reklamować swoim wyglądem. W ten sposób można ograniczyć wydatki na reklamę i fundusze przeznaczyć np. na utworzenie dodatkowych miejsc pracy. Z zakładów, które ulokowały się w pobliżu drogi nr 210 można wymienić m.in.: „BAJCAR” Bronisław Bajcar, „M\&S Okna i Drzwi” Sp. z o.o., „SLUZAN”Sp. z o.o., „SOBCAR”Sp. z o.o., „KAMIR” Sp. z o.o.

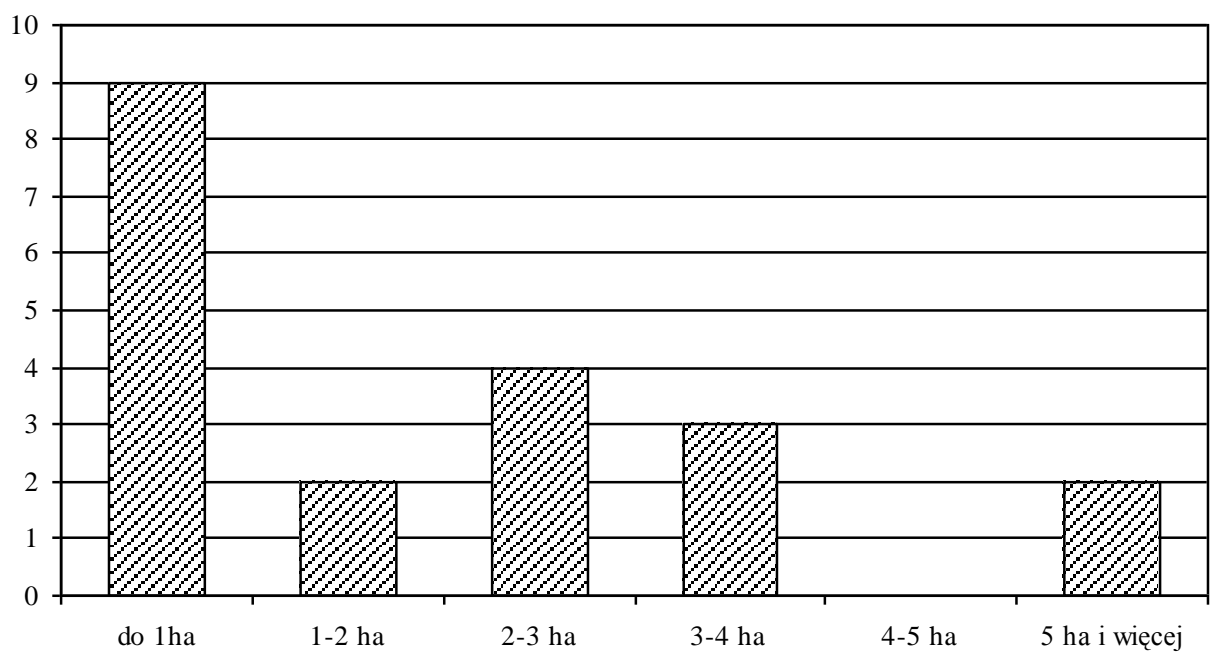

Ryc. 5. Podział działek inwestycyjnych zakupionych przez firmy ze względu na powierzchnię

Interesującym problemem jest zagadnienie dotyczące preferowanych rodzajów działalności, jaką prowadzi się w strefie. Z badań, jakie przeprowadzono we wrześniu 2002 r. wynika, że wiodącymi dziedzinami produkcji jest uzyskiwanie wyrobów zaliczanych zasadniczo do:

- przemysłu elektromaszynowego i elektronicznego,

- przetwórstwa rolno-spożywczego, w tym szczególnie przetwórstwa rybnego, 
- przetwórstwa tworzyw sztucznych,

- produkcji wyrobów przemysłu drzewno-meblarskiego,

- przemysłu skórzanego.

Zjawisko to potwierdza w znacznym stopniu zajmowana powierzchnia trwałego zainwestowania w SSSE według rodzajów działalności (ryc. 6). Według tego kryterium zdecydowanie najsilniejszą branżę stanowi produkcja zbiorników i cystern. Ambicją zakładów tej branży jest bycie najlepszym europejskim producentem zbiorników na gaz ciekły oraz naturalny w celu zapewnienia ekologicznego zasilania pojazdów osobowych i dostawczych. Przykładowo od ponad 33 lat Zakład Wyrobów Metalowych „STAKO” s.c. produkuje zbiorniki ciśnieniowe o różnych wielkościach i pojemnościach. Od 10 lat zajmuje się głównie konstruowaniem i produkcją zbiorników LPG (Liquefied Petroleum Gas) do napędu pojazdów samochodowych. Produkty dostarczane są do różnych państw w Europie, Azji i Afryce. Na szczególne podkreślenie, biorąc pod uwagę powierzchnię zakładu, zatrudnienie jak i nakłady inwestycyjne, zasługują Zakłady Konstrukcji Metalowych „ZASTA-POLSKA” Sp. z o.o. specjalizujące się w produkcji zbiorników na gaz i paliwa płynne, a ostatnio w konstruowaniu siłowni wiatrowych. „ZASTA-POLSKA” posiada certyfikaty dopuszczeniowe, w tym: Urzędu Dozoru Technicznego, Polskiego Rejestru

Statków,

ISO 9002, GOST ROSJI, Wojskowego Dozoru Technicznego.

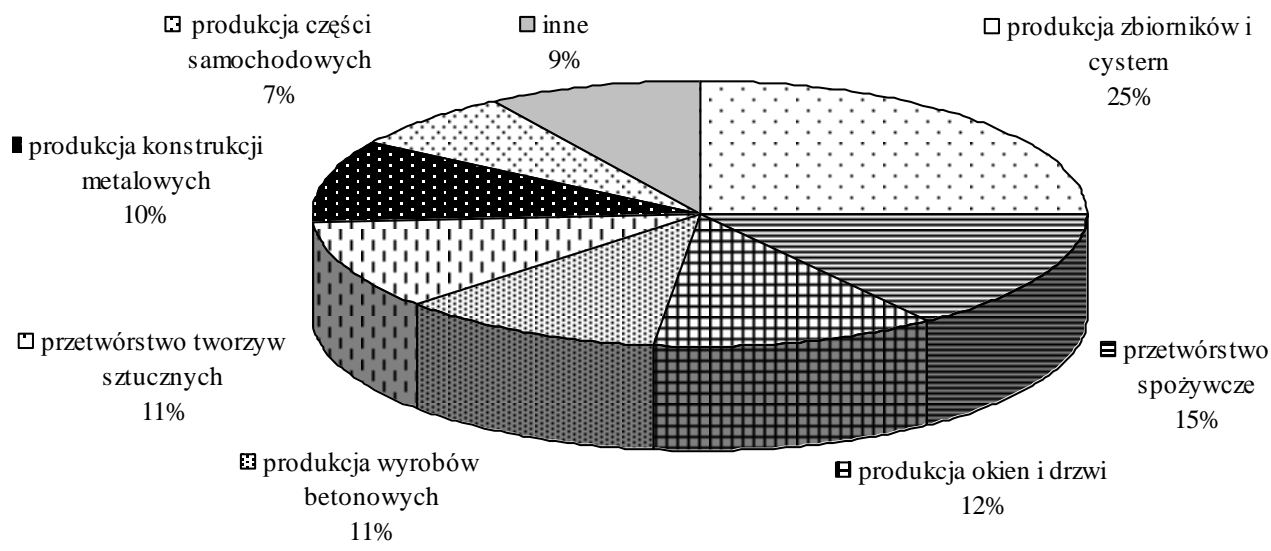

Ryc. 6. Odsetek powierzchni zajmowanej przez inwestorów w Słupskiej Specjalnej Strefie Ekonomicznej według rodzajów działalności w 2002 r.

Ważne miejsce w strefie zajmują Zakłady Przetwórstwa Rybnego „ŁOSOŚ” Sp. z o.o. Przedmiotem działalności jest przede wszystkim przetwórstwo ryb i owoców morza. Produkcja jest w 83,6\% kierowana na rynek krajowy. Około 60\% sprzedaży krajowej kierowana jest do zorganizowanych sieci hurtowych i detalicznych, takich jak: Makro, HIT, Auchan, Geant, Netto. Sprzedaż na eksport stanowi około 16\%. Odbiorcami zagranicznymi są m.in. Kanada, Australia, Słowacja, Czechy, Węgry.

$\mathrm{Na}$ uwagę zasługują zakłady zajmujące się produkcją okien i drzwi z PCV (firma „BAJCAR” Bronisław Bajcar) oraz „M\&S Okna i Drzwi” Sp. z o.o. produkująca okna 
i drzwi z różnych gatunków drzewa (sosna, buk). Zajmują one trzecie miejsce pod względem powierzchni trwale zainwestowanej, jak również zatrudnienia. Produkcja tych firm w około $90 \%$ przeznaczona jest na rynek krajowy. Kolejne miejsca, biorąc pod uwage powierzchnię zajętą pod trwałe zainwestowanie, wartość produkcji, a także liczbę miejsc pracy zajmują firmy zaliczane do przetwórstwa tworzyw sztucznych oraz produkcji wyrobów betonowych.

W połowie lat dziewięćdziesiątych, kiedy powstał projekt powołania Słupskiej Specjalnej Strefy Ekonomicznej, niemal każdy był zachwycony i miał nadzieję, że pomoże to rozwiązać problemy regionu słupskiego. Po pięciu latach funkcjonowania strefy można stwierdzić, że plany zostały tylko częściowo zrealizowane. Jedna z najmniejszych pod względem powierzchni w skali kraju SSSE (168 ha na 6000 ha terenów zarezerwowanych dla stref ekonomicznych w całym kraju), mimo że gwarantowała całkowite zwolnienie od podatku dochodowego, nie otrzymała zbyt wielu ofert od firm chcących inwestować w strefie. Przedsiębiorcy liczyli się z tym, że w SSSE wszystko trzeba budować od podstaw. Nie udało się też Pomorskiej Agencji Rozwoju Regionalnego S.A. - mimo czynionych wysiłków - znaleźć inwestora strategicznego. W stosunku do pozostałych specjalnych stref ekonomicznych kraju SSSE zdecydowanie odbiega w zakresie wielkości realizowanych inwestycji, jak i zatrudnienia, choć w tym drugim przypadku różnice są zdecydowanie mniejsze. O ile w całym kraju od początku działania Specjalnych Stref Ekonomicznych

zainwestowano na ich obszarze $10 \mathrm{mld} \mathrm{zl}$, to w strefie słupskiej inwestycje wynoszą około $53 \mathrm{mln}$ zł (0,53\%). W przypadku liczby zatrudnionych udział strefy słupskiej jest bardziej korzystny i wynosi 1,9\%. Z porównania tych wielkości można wnioskować, że 1 miejsce pracy w strefie słupskiej jest mniej kosztowne i że powstają one generalnie w firmach o mniejszej liczbie zatrudnionych z sektora małych i średnich przedsiębiorstw.

W przeciwieństwie do innych stref, w SSSE nie było na początku żadnej infrastruktury, dlatego też o wiele trudniej było podjąć decyzje o lokowaniu tu inwestycji. Przykładowo w strefie katowickiej czy mieleckiej funkcjonowały wcześniej duże zakłady, które od razu zapewniały inwestorom dobrze rozwiniętą infrastrukturę. W przypadku strefy słupskiej brak było np. drogi dojazdowej.

W kolejnych latach dzięki inicjatywie zarządzających Słupską Specjalną Strefą Ekonomiczną udało się zmienić część „nieinwestycyjnych” gruntów pod Włynkówkiem na tereny w Redzikowie, które lepiej nadają się pod inwestycje. Pomorska Agencja Rozwoju Regionalnego zweryfikowała początkowe plany, które zakładały znalezienie inwestora strategicznego i zatrudnienie na terenie strefy 5 tys. osób. Obecnie siłą słupskiej strefy stały się firmy sektora małych i średnich przedsiębiorstw. One to coraz częściej wdrażają nowe technologie, rezygnują z zatrudnienia dużej liczby pracowników.

Choć obecny poziom zatrudnienia w SSSE (750 osób po pięciu latach jej funkcjonowania przy 40 tys. miejsc pracy w Specjalnych Strefach Ekonomicznych w skali kraju) nie daje zbyt wielkich powodów do zadowolenia, to sam fakt, że teren wokół byłej fabryki domów nie jest zarośniętym polem należy uznać ze wszech miar za pozytywne zjawisko. Zaznaczyć trzeba, że około 300 osób pracuje w firmach kooperujących z przedsiębiorstwami z SSSE.

Ze złożonych deklaracji i wydanych zezwoleń wynika, że na terenie strefy ma powstać kolejnych 750 miejsc pracy. Można też żywić nadzieję, uwzględniając coraz korzystniejsze warunki do inwestowania (zagospodarowanie w zakresie infrastruktury), że w końcu pojawi się podmiot gospodarczy, który okaże się inwestorem strategicznym. 


\section{Literatura}

Bielecki J., 2002, Ustepstwa z obu stron, „Rzeczpospolita”, nr 119 (6196), s. B2

Bielecki J., 2001, Specjalne strefy do rewizji, „Rzeczpospolita”, nr 91 (5864)

Korycińska T., Funkcjonowanie specjalnych stref ekonomicznych wPolsce i ich udziat w pobudzaniu gospodarki danego regionu, Departament Rozwoju Regionalnego - Ministerstwo Gospodarki, Warszawa

Korżak D., 2002, „Słupska Specjalna Strefa Ekonomiczna i tendencje jej rozwoju”, praca magisterska napisana w Instytucie Geografii PAP, pod kier. E. Rydza, Słupsk

Kraskowski L., 1999, Strefy nie spetnionych marzeń, „Rzeczpospolita”, nr 215, s. B2

Lubinecka L., 1997, Strefa specjalnych przywilejów, „Głos Słupski”, nr 29, s. 7

Niklewicz K., 2002, Strefy zamknięte, „Gazeta Wyborcza”, nr 175 (4083), s. 20

Ofiarska E., 2000, Specjalne strefy ekonomiczne w Polsce - zagadnienia publicznoprawne, Szczecin

Oktaba L., 1997, Technoparki w Krakowie i Modlinie, ,Rzeczpospolita”, nr 240 (4797), s. 10

Oktaba L., 2001, Mniej specjalnych stref ekonomicznych, „Rzeczpospolita”, nr 62 (5835) s. B2

Plan operacyjny na 2002 rok dla Stupskiej Specjalnej Strefy Ekonomicznej, 2001, Pomorska Agencja Rozwoju Regionalnego S.A., Słupsk

Plan Rozwoju Stupskiej Specjalnej Strefy Ekonomicznej, 2001, Pomorska Agencja Rozwoju Regionalnego S.A. Słupsk

Polskie Specjalne Strefy Ekonomiczne, 2000, praca zbiorowa pod red. E. Kryńskiej, Warszawa

Przybylski M., 2000, Pomoc państwa reglamentowana, „Rzeczpospolita”, nr 32 (5502), s. B2

Rajman J., 1989, Dynamika kształtowania sie stref zurbanizowanych (Metody analizy struktur spoteczno-zawodowych na przykładzie aglomeracji Górnoślaskiego Okręgu Przemystowego), [w:] Studia nad urbanizacja poludniowej Polski, Kraków, s. 98-118

Rydz E., Zaleski J., 1992, Rola i funkcje Stupska na tle sieci osadniczej Środkowego Wybrzeża, Słupsk

Specjalne strefy ekonomiczne - kłopoty czy korzyści, 2000, „Gazeta Prawna”, nr 46, s. 17 (dodatek: „Gazeta Gospodarcza”)

Problemy integracji międzynarodowej przemystu w procesie przechodzenia do gospodarki rynkowej, 2000, pod red. Z. Zioło, Warszawa-Kraków 